\title{
Mutation analysis of five candidate genes in Chinese patients with hypospadias
}

\author{
Yanping Wang ${ }^{1,3,4}$, Qiang $\mathrm{Li}^{1,2,4}$, Jiajie $\mathrm{Xu}^{2}$, Qingjie $\mathrm{Liu}^{3}$, Weiqiu Wang ${ }^{1,3}$, Yi Lin ${ }^{1}, \mathrm{Fen} \mathrm{Ma}^{3}$, \\ Taiji Chen ${ }^{1,3}$, Senkai $\mathrm{Li}^{2}$ and Yan Shen*,1,3
}

${ }^{1}$ Institute of Basic Medical Sciences, PUMC\&CAMS, Beijing, 100005, China; ${ }^{2}$ Plastic Surgery Hospital, PUMC\&CAMS, Beijing, 100041, China; ${ }^{3}$ Chinese National Human Genome Center, Beijing, 100176, China

Hypospadias is the displacement of the urethral meatus from the tip of the glans to the ventral side of the phallus. During fetal development, SRY, SOX9, WT1, SRDSA2 and $A R$ are important at different stages in the differentiation and development of the male genital system. Mutations in these genes impair masculinization and may be associated with hypospadias. In order to explore these possibilities, we employed polymerase chain reaction and direct sequencing to analyze the coding regions of these five genes in 90 Chinese hypospadias patients. We found a total of 16 different mutations in SRD5A2, AR and WT1 in 24 of these 90 patients. Seven mutations are novel. No mutation was found in SRY or SOX9. SNP V89L found in SRD5A2 was statistically significant between patients and controls. Our results indicated that mutations in SRD5A2, AR and WT1 were associated with hypospadias. In conclusion, mutations are frequently found in genes that control androgen action and metabolism, but are seldom found in genes active in the early phase of sex determination and differentiation. Mutations in AR, SRD5A2 or WT1 seem to be associated not only with hypospadias but also with micropenis.

European Journal of Human Genetics (2004) 12, 706-712. doi:10.1038/sj.ejhg.5201232

Published online 21 July 2004

Keywords: hypospadias; SRY gene; SOX9 gene; WT1 gene; SRD5A2 gene; AR gene

\section{Introduction}

Hypospadias (OMIM 146450) is a disorder of male external genital development in which the urethral orifice is found on the ventral surface of the penis rather than at the tip of the glans. It is a common congenital abnormality with an incidence of $0.03-0.4 \%{ }^{1}$ It may be classified as simple (glandular or penile) or severe (penoscrotal, scrotal or perineal) on the basis of the anatomical location of the urethral meatus. The cause of hypospadias is complex and poorly understood. In most cases it occurs sporadically, but families exist in which hypospadias segregates as a

*Correspondence: Dr Y Shen, Department of Biochemistry \& Molecular Biology, Institute of Basic Medical Sciences, CAMS and PUMC, 5, Dong Dan San Tiao, 100005, Beijing, People's Republic of China.

Tel: + 8610 65296486; Fax: +86 10 86781036;

E-mail: sheny@chgb.org.cn

${ }^{4}$ Both authors contributed equally to this work.

Received 16 January 2004; revised 30 March 2004; accepted 7 May 2004 dominant trait, showing that a genetic cause is undoubtedly involved in at least a subset of cases. ${ }^{2}$ Multifactorial models have yielded heritability indices ranging from 57 to $74 \%$ from pedigree data, indicating a multifactorial model of inheritance. ${ }^{3}$

Normal male genital development involves a coordinated interplay between several gene products (Figure 1), all of which are important for normal male reproductive tract development. The sex-determining region $\mathrm{Y}$ gene $(S R Y)$ is the initial switch to male sexual differentiation by triggering development of Sertoli cells. SRY box 9 (SOX9) may be the direct downstream target of SRY in the sexdetermination cascade, ${ }^{4}$ and is involved in the regulation of Sertoli cell-specific expression of anti-Müllerian hormone and the synthesis of testosterone in fetal testes. ${ }^{5}$ The Wilms' tumor 1 gene (WT1) is a long-term expression gene during embryonic sex development and has a male-specific role in earlier and later sex determination. ${ }^{4,6}$ Heterozygous 


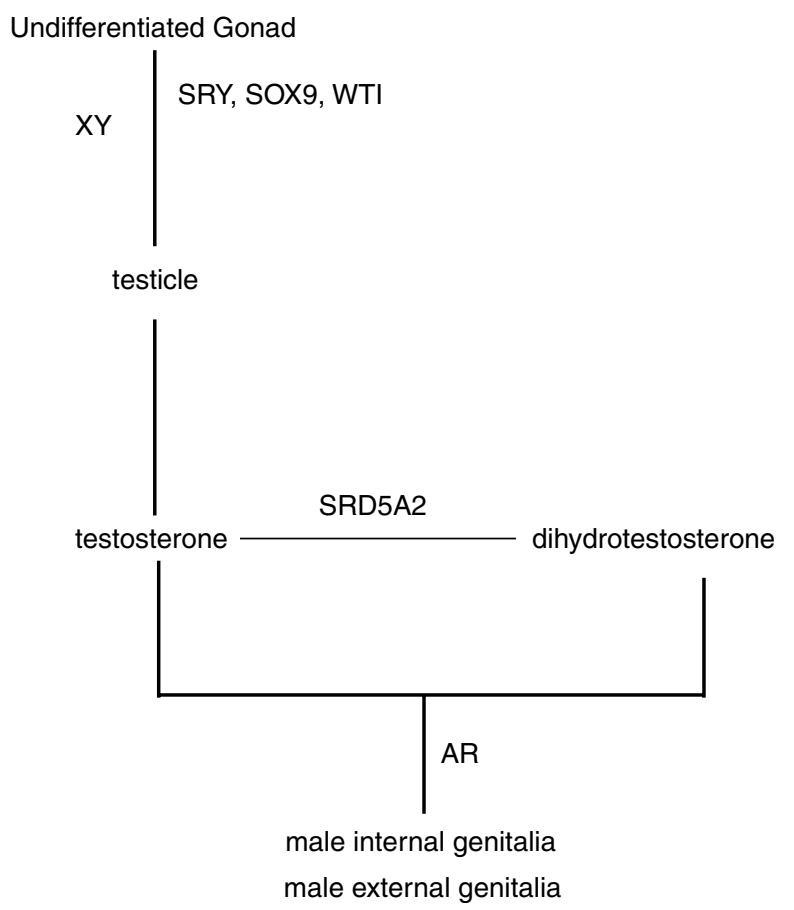

Figure 1 Simplified scheme of male sex differentiation and sex organ formation.

loss-of-function germ-line mutations in $W T 1$ are associated with mild effects on sexual differentiation, including hypospadias and cryptorchidism. ${ }^{7}$ Development of the urethral and external genital system in the male fetus is an androgen-dependent process, requiring dihydrotestosterone (DHT) formed from testosterone by the action of steroid $5 \alpha$-reductase type 2 (SRD5A2). Mutations of SRD5A2 that reduce or inhibit enzyme activity result in diminished DHT formation, and cause masculinization defects of varying degrees, including hypospadias. ${ }^{8}$ Both DHT and its precursor, testosterone, have their biological activities via binding to the androgen receptor $(A R)$, which subsequently binds to the androgen-responsive element on DNA and regulates gene transcription. ${ }^{9}$ It has been demonstrated that mutations of $A R$ are definitely associated with hypospadias. ${ }^{10-12}$

SRY, SOX9, WT1, SRD5A2 and AR are important in the development of the male genital system and act at different stages, with SRY and SOX9 acting at early stages, $S R D 5 A 2$ and $A R$ at late stages, and $W T 1$ at all stages. Mutations in these genes impair masculinization and may be associated with hypospadias. In order to explore these possibilities and to investigate the mutation distribution, the five genes were selected for analysis in Chinese hypospadias patients and normal controls.

\section{Materials and methods Experimental subjects}

We identified 90 Chinese patients with hypospadias from the Hypospadias Treating Center of the Plastic Surgery Hospital affiliated with the Peking Union Medical College. Clinical phenotypes, family histories and complications of the 90 patients are listed in Table 1 . All patients included were $46, X Y$. Informed consent was obtained from all patients or their parents.

A total of 276 unrelated, normal Chinese males were included as the comparison group. Control group 1 consisted of 96 subjects whose DNA was sequenced for all loci where mutations were found in hypospadias cases; control group 2 consisted of 180 subjects whose DNA was examined to determine the occurrence of novel mutations first identified in cases. The mean age of both control groups was 27 years. Routine medical examinations were performed on all controls before they were enrolled in the study.

Table 1 Clinical data of 90 patients with hypospadias

\begin{tabular}{|c|c|c|c|c|c|}
\hline Type of hypospadias & Glandular & Penile & Penoscrotal & Scrotal & Perineal \\
\hline $\begin{array}{l}\text { No. of cases } \\
\text { Average age (years) }\end{array}$ & $\begin{array}{l}7(7.8 \%) \\
9.0\end{array}$ & $\begin{array}{l}22(24.4 \%) \\
10.3\end{array}$ & $\begin{array}{c}33(36.7 \%) \\
9.2\end{array}$ & $\begin{array}{c}17(18.9 \%) \\
14.6\end{array}$ & $\begin{array}{l}11(12.2 \%) \\
10.9\end{array}$ \\
\hline $\begin{array}{l}\text { Family history } \\
\text { Hypospadias } \\
\text { Sterile } \\
\text { Other deformities }{ }^{a}\end{array}$ & $\begin{array}{l}5 \\
2 \\
3 \\
0\end{array}$ & $\begin{array}{l}6 \\
0 \\
2 \\
3\end{array}$ & $\begin{array}{r}19 \\
3 \\
3 \\
7\end{array}$ & $\begin{array}{r}14 \\
4 \\
0 \\
6\end{array}$ & $\begin{array}{l}7 \\
3 \\
2 \\
2\end{array}$ \\
\hline $\begin{array}{l}\text { Complications } \\
\text { Micropenis } \\
\text { Cryptorchidism } \\
\text { Gynecomastia } \\
\text { Hernia }\end{array}$ & $\begin{array}{l}5 \\
3 \\
0 \\
2 \\
0\end{array}$ & $\begin{array}{l}4 \\
3 \\
1 \\
0 \\
0\end{array}$ & $\begin{array}{r}16 \\
9 \\
3 \\
2 \\
1\end{array}$ & $\begin{array}{r}17 \\
10 \\
3 \\
1 \\
1\end{array}$ & $\begin{array}{r}11 \\
5 \\
2 \\
3 \\
0\end{array}$ \\
\hline
\end{tabular}

${ }^{a}$ Other deformities include: cleft lip, cleft palate, deformities of hand and heart, etc.

bMicropenis: length of penis is more than $-2.5 \mathrm{SD}$ from the average penile length in males of matched age. 


\section{Polymerase chain reaction (PCR) amplification and} sequencing

Genomic DNA was extracted from the peripheral blood leukocytes of patients using standard procedures. PCR was performed to amplify all the exons and the exon-intron boundaries of SRD5A2, AR, WT1, SOX9 and the single exon of $S R Y$ with primers that we designed using Premier 5.0 software (Table 2). Exon 1 of $A R$, exons 1 and 5 of SRD5A2, exon 1 of $W T 1$, single exon of $S R Y$ and exons 1 and 3 of SOX9 were divided into seven, two, five, two, two, two and three segments, respectively, during their amplification in order to facilitate their subsequent sequencing. PCR was performed in a $50 \mu \mathrm{l}$ volume and thermal cycling was performed in a GeneAmp PCR System 2700 (Perkin-Elmer, Applied Biosystems, Foster City, CA, USA) (detailed PCR conditions are available upon request).

PCR products were purified using MultiScreen-PCR plate (Millipore). Using sequencing primers (Table 2), the purified PCR products were sequenced directly with the ABI 3700 DNA sequencer (Perkin-Elmer, Applied Biosystems, Foster City, CA, USA). Sequencing results were analyzed using the Phred/Phrap/Consed software. When differences from the normal were found, purified PCR products from these patients were sequenced again to

Table 2 Primers sets for PCR

\begin{tabular}{|c|c|c|c|}
\hline Gene & Exons & Forward primers & Reverse primers \\
\hline SRD5A2 & $\begin{array}{l}1 \mathrm{~A} \\
1 \mathrm{~B} \\
2 \\
3 \\
4 \\
5 \mathrm{~A} \\
5 \mathrm{~B} \\
5 \mathrm{C} \\
5 \mathrm{D} \\
5 \mathrm{E}\end{array}$ & $\begin{array}{l}\text { tgagaaaggggtattgctgcg } \\
\text { tgcaggttcagtgccagcagagc } \\
\text { gaggtggggatgagaccatgttc } \\
\text { ccctcctttcattttagcttagttg }^{\mathrm{a}} \\
\text { ttcttgctgccttgtgtatttg }^{\mathrm{a}} \\
\text { taactgtaggttgacttgtaacaaag }^{\mathrm{a}} \\
\text { agttactcctacccttccag }^{\mathrm{a}} \\
\text { agaccttgaatacaggagccc }^{\mathrm{a}} \\
\text { tacagcagaagccccaagcaac }^{\mathrm{a}} \\
\text { atacagagcccacatttccacacc }\end{array}$ & $\begin{array}{l}\text { aggtggcccgaagagggag } \\
\text { ttggcgttcctcggtgcgcg } \\
\text { gtttgcgatgggaaatggc } \\
\text { ttcgtgccctcactgtccc } \\
\text { ttcggtttctcaatcttcctctgc } \\
\text { catgtacttggattgcccgg } \\
\text { aatagccataccagttttccg } \\
\text { ttttctgcccagacgtgcc } \\
\text { gcattccgcaaacataggcc }{ }^{a} \\
\text { tctttatttccagcacacagccc }\end{array}$ \\
\hline$A R$ & $\begin{array}{l}1 \mathrm{~A} \\
1 \mathrm{~B} \\
1 \mathrm{C} \\
1 \mathrm{D} \\
1 \mathrm{E} \\
1 \mathrm{~F} \\
1 \mathrm{G} \\
2 \\
3 \\
4 \\
5 \\
6 \\
7 \\
8\end{array}$ & 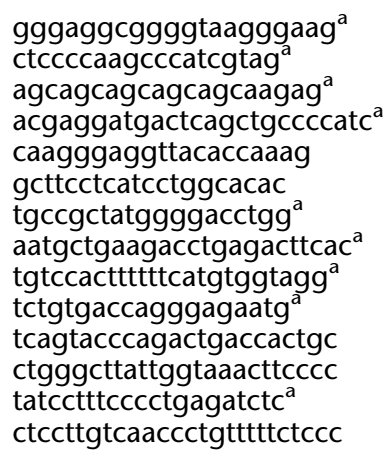 & $\begin{array}{l}\text { ccgactgcggctgtgaagg }^{\mathrm{a}} \\
\text { tgtcagaaatggtcgaagtgc } \\
\text { ttaagccggggaaatggg } \\
\text { gtagtccagcgggttctccagcttg }^{\mathrm{a}} \\
\text { atacaactggccttcttcgg }^{\mathrm{a}} \\
\text { cgaaaggcgacatttctgg }^{\mathrm{a}} \\
\text { cggtgaagtcgcttcctg } \\
\text { taagttatttgatagggccttgcc } \\
\text { cacgttgcctatgaaagggtcag } \\
\text { cttatctcatgctcccacttc }^{\text {ccatcaccaccaaccaggtctg }} \\
\text { tttaatggcaaaagtggtcctctc } \\
\text { gctgttctcctgataaagcacc } \\
\text { gaacatgttcatgacagactgtac }\end{array}$ \\
\hline WT1 & $\begin{array}{l}1 \mathrm{~A} \\
1 \mathrm{~B} \\
2 \\
3 \\
4 \\
5 \\
6 \\
7 \\
8 \\
9 \\
10\end{array}$ & $\begin{array}{l}\text { gccagagcagcagggagtc } \\
\text { ttcggcttacgggtcgttg } \\
\text { caccgctgacactgtgcttc } \\
\text { ccaggctcaggatctcgtg } \\
\text { ttgtggttatgtgtctaactc } \\
\text { gggacttagttcagcactcttg } \\
\text { aaaaccatcattccctcctg }^{\mathrm{a}} \\
\text { taaagcctcccttcctcttac } \\
\text { atcccttttccagtatcattttc } \\
\text { ggggactggggaaatctaag } \\
\text { tcagggacagaatgatggg }\end{array}$ & $\begin{array}{l}\text { ccggaaaagtggacagtgaagg }^{\text {a }} \\
\text { cgcttccgctatcctcacg }^{\mathrm{a}} \\
\text { ccttttagatgtcctccttgc }^{\mathrm{a}} \\
\text { tccaagacccagcatgcc } \\
\text { aggaggaaagcgttctaatgtcac }^{\mathrm{a}} \\
\text { aatgctacctgattacccac } \\
\text { gggccaaagagtccatcag } \\
\text { aaagcagtgcttactttccatc }^{\mathrm{a}} \\
\text { gggtgttcctttcttctttttc } \\
\text { agccacgcactattccttc }^{\mathrm{a}} \\
\text { taaaagtaggcagggcagag }^{\mathrm{a}}\end{array}$ \\
\hline$S R Y$ & $\begin{array}{l}1 \mathrm{~A} \\
1 \mathrm{~B}\end{array}$ & $\begin{array}{l}\text { tcagcagggcaagtagtc }{ }^{a} \\
\text { tagagtgaagcgacccatg }^{a}\end{array}$ & $\begin{array}{l}\text { gtggctttcgtacagtcatc }{ }^{a} \\
\text { tgtccgtttgtatcaagttag }^{a}\end{array}$ \\
\hline sox9 & $\begin{array}{l}1 \mathrm{~A} \\
1 \mathrm{~B} \\
2 \\
3 \mathrm{~A} \\
3 \mathrm{~B} \\
3 \mathrm{C}\end{array}$ & $\begin{array}{l}\text { tgagccacagttacaccccattc } \\
\text { cttgacgtgcggcttgttc } \\
\text { gtgttgtttggatgcctcttag } \\
\text { tttgggtacgagttgccttag } \\
\text { ggtgaaggtggagtagaggc } \\
\text { ctcagcgtggtcagcgtg }\end{array}$ & $\begin{array}{l}\text { gcgagcccgatctgaagaag }^{a} \\
\text { cgccttcctaagtgctcgc }^{a} \\
\text { ggaagccgagtggtctgg } \\
\text { gcactcgcccaacagatc } \\
\text { tacacgggcagctacgg } \\
\text { gcactcgcccaacagatc }^{\text {a }}\end{array}$ \\
\hline
\end{tabular}

${ }^{\text {aAlso }}$ used for sequencing. 
confirm the original results. In addition, purified PCR products from some patient parents and normal controls were sequenced for analysis.

\section{Statistical analysis}

The software Epi 5.0. was used for statistical analysis of genotypic and allele distribution of detected SNPs. Test for statistical differences was performed using the $\chi^{2}$ test or Fisher's exact test, as appropriate. Odds ratios (OR) and 95\% confidence intervals (95\% CIs) were also calculated for SNPs found to be significant by pairwise comparisons.

\section{Results}

We found a total of 16 different mutations in SRD5A2, AR and $W T 1$ genes in 24 of our 90 hypospadias patients and seven parents (Table 3). No mutation was found in $S R Y$ or SOX9. Eight different mutations were found in SRD5A2 in 14 of our cases. Three are novel (Q6X, nt656 delT, H232H).
Three different novel mutations were found in $W T 1$ in four of our patients. Five different mutations were found in $A R$ in six of our patients. One is novel (L859L). The $A R$ contains a polymorphic CAG repeat sequence for the polyglutamine tract in exon 1 . CAG repeat numbers were obtained only in 61 patients because repeat sequences were often unreadable with the direct sequencing methods used. The repeat lengths were from 22 to 25 and within the normal range. No mutations in SRY, SOX9, WT1 and AR were found in control group 1. G203S and F234L in $S R D 5 A 2$ were found in four and one controls, respectively, in control group 1, and $\mathrm{H} 232 \mathrm{H}$ in SRD5A2 was found in one control in control group 2.

In all, 10 SNPs were found in SRD5A2,WT1 and SOX9 genes. Three SNPs in SRD5A2 were detected. One is novel: G/A in $3^{\prime}$ UTR of exon 5 (dbSNP accession number ss\# 12675709). One was statistically significant $(P=0.007)$ (Table 4): nucleotide $265 \mathrm{G} / \mathrm{C}$ in exon 1 , which leads to amino acid V89L. Six SNPs in WT1 and one SNP in SOX9

Table 3 Genotype and phenotype of patients carrying mutations

\begin{tabular}{|c|c|c|c|c|c|c|c|c|c|c|}
\hline \multirow{2}{*}{ Gene } & \multirow{2}{*}{$\begin{array}{l}\text { Patient } \\
\text { no. }\end{array}$} & \multirow{2}{*}{ Nt. change } & \multirow{2}{*}{$\begin{array}{c}\text { Amino-acid } \\
\text { change }\end{array}$} & \multirow{2}{*}{ Exon } & \multirow{2}{*}{ Allele ${ }^{a}$} & \multicolumn{4}{|c|}{ Phenotype } & \multirow{2}{*}{ Others } \\
\hline & & & & & & $\begin{array}{l}\text { Hypospadias } \\
\text { type }\end{array}$ & Micropenis $^{b}$ & $\begin{array}{l}\text { Bifid } \\
\text { scrotal }\end{array}$ & $\begin{array}{l}\text { Other } \\
\text { abnormal }\end{array}$ & \\
\hline \multirow[t]{6}{*}{$A R$} & 4 & $1991 C>T$ & 1664T & 4 & Hem & Glanular & No & No & Gynecomastia & \multirow{6}{*}{$\begin{array}{l}\text { Mother was } \mathrm{Het}^{\mathrm{a}} \mathrm{R} 840 \mathrm{H} \\
\text { Mother and maternal- } \\
\text { grandmother were Het } \\
\text { I842T } \\
\text { Mother was } \mathrm{Het}^{\mathrm{a}} \mathrm{R} 855 \mathrm{H}\end{array}$} \\
\hline & 86 & $2519 G>A$ & $\mathrm{R} 840 \mathrm{H}$ & 7 & Hem & Perineal & Yes & Yes & Not found & \\
\hline & 84 & $2525 \mathrm{~T}>\mathrm{C}$ & $\mathrm{I} 842 \mathrm{~T}$ & 7 & Hem & Scrotal & Yes & Yes & Not found & \\
\hline & 8 & $2564 G>A$ & $\mathrm{R} 855 \mathrm{H}$ & & Hem & Perineal & Yes & Yes & Not found & \\
\hline & 9 & $2564 G>A$ & $\mathrm{R} 855 \mathrm{H}$ & 7 & Hem & Perineal & Yes & Yes & Not found & \\
\hline & 1 & $2577 C>A$ & L859L & 7 & Hem & Penile & No & No & Not found & \\
\hline \multirow[t]{18}{*}{ SRD5A2 } & 83 & $16 \mathrm{C}>\mathrm{T}$ & Q6X & 1 & Hom & Scrotal & Yes & Yes & Cryptorchidism & \multirow{18}{*}{$\begin{array}{l}\text { Father was Het }{ }^{\mathrm{a}} \text { Q6X } \\
\text { Mother was Het }{ }^{\mathrm{a}} \text { G203S }\end{array}$} \\
\hline & 44 & $607 G>A$ & G203S & 4 & Hom & Perineal & Yes & Yes & Not found & \\
\hline & 39 & $680 G>A$ & $\mathrm{R} 227 \mathrm{Q}$ & 4 & Hom & Scrotal & Yes & Yes & Not found & \\
\hline & 73 & $680 G>A$ & $\mathrm{R} 227 \mathrm{Q}$ & 4 & Hom & Penile & No & Yes & Not found & \\
\hline & 81 & $737 \mathrm{G}>\mathrm{A}$ & R246Q & 5 & Hom & Scrotal & No & Yes & Cryptorchidism & \\
\hline & 16 & $16 C>T$ & Q6X & 1 & Het & Scrotal & Yes & Yes & Cryptorchidism & \\
\hline & & $607 \mathrm{G}>\mathrm{A}$ & G203S & 4 & Het & & & & & \\
\hline & 87 & $607 \mathrm{G}>\mathrm{A}$ & G203S & 4 & Het & Scrotal & Yes & Yes & Not found & \\
\hline & & $671 \mathrm{~T}>\mathrm{A}$ & $\mathrm{L} 224 \mathrm{H}$ & 4 & Het & & & & & \\
\hline & 88 & $607 \mathrm{G}>\mathrm{A}$ & G203S & 4 & Het & Scrotal & Yes & Yes & Not found & \\
\hline & & $671 \mathrm{~T}>\mathrm{A}$ & L224H & 4 & Het & & & & & \\
\hline & 89 & $607 \mathrm{G}>\mathrm{A}$ & G203S & 4 & Het & Scrotal & Yes & Yes & Not found & \\
\hline & & $671 \mathrm{~T}>\mathrm{A}$ & $\mathrm{L} 224 \mathrm{H}$ & 4 & Het & & & & & \\
\hline & 64 & $607 \mathrm{G}>\mathrm{A}$ & G203S & 4 & Het & Penile & No & Yes & Not found & \\
\hline & 20 & 656delT & & 4 & Het & Perineal & Yes & Yes & Cryptorchidism & \\
\hline & 56 & $680 \mathrm{G}>\mathrm{A}$ & $\mathrm{R} 227 \mathrm{Q}$ & 4 & Het & Glanular & No & No & Not found & \\
\hline & 60 & $696 \mathrm{~T}>\mathrm{C}$ & $\mathrm{H} 232 \mathrm{H}$ & 4 & Het & Scrotal & No & Yes & Not found & \\
\hline & 40 & $702 C>G$ & F234L & 5 & Het & Penoscrotal & Yes & Yes & Not found & \\
\hline \multirow[t]{4}{*}{ WT1 } & 74 & $390 \mathrm{C}>\mathrm{T}$ & N130N & 1 & Het & Penoscrotal & Yes & No & Not found & \\
\hline & 79 & $390 C>T$ & N130N & 1 & Het & Penile & No & No & Not found & \\
\hline & 85 & $391 G>A$ & A131T & 1 & Het & Penile & No & No & Not found & \\
\hline & 65 & $477 \mathrm{C}>\mathrm{T}$ & S159S & 2 & Het & Glanular & No & No & Not found & \\
\hline
\end{tabular}

${ }^{a}$ Hem: hemizygous; Het: heterozygous; Hom: homozygous.

${ }^{\mathrm{b}}$ Micropenis: length of penis is more than $-2.5 \mathrm{SD}$ from the average penile length in males of matched age. 
Table 4 Genotype distribution of V89L in patients and controls (exon 1 of SRD5A2; nucleotide 265)

\begin{tabular}{lccc}
\hline & & Patients & Controls \\
\hline Genotype & C/C & 22 & 12 \\
& G/C & 52 & 44 \\
& G/G & 16 & 31 \\
Allele frequencing & Total & 90 & 87 \\
& C & 0.53 & 0.39 \\
& $\mathrm{G}$ & 0.47 & 0.61 \\
\hline
\end{tabular}

${ }^{\text {a }}$ Significantly elevated in patients, $P=0.007$ ( $\chi^{2}$ test).

were found, respectively, and all of them were not statistically significant.

\section{Discussion}

In our study, four homozygous mutations of SRD5A2 were identified in five patients. Patients 83 and 81 had scrotal hypospadias with cryptorchidism and bifid scrotum. Q6X was found in patient 83, and the mutant product is expected to contain only six amino acids, resulting in loss of enzyme activity. R246Q was found in patient 81. Thigpen et $a l^{13}$ reported two patients who carried homozygous R246Q with perineoscrotal hypospadias, microphallus and cryptorchidism. This mutation reduces enzyme activity and affects the nicotinamide adenine dinucleotide phosphate (NADPH) $\mathrm{Km}$ in cultured genital skin fibroblasts. G203S was found in patient 44 with perineal hypospadias, bifid scrotum and micropenis. G203 is a conserved amino acid between human and mice, and it is possible that this variant contributed to severe phenotype of patient 44 . Patients 39 and 73 carried the same mutation, $\mathrm{R} 227 \mathrm{Q}$, which is one of the most common mutations in Chinese patients. ${ }^{14}$ It is known to inhibit NADPH binding, to reduce the binding of testosterone to the enzyme and the half-life of the protein. ${ }^{8,13}$ Patient 39 had scrotal hypospadias with micropenis and bifid scrotum, while patient 73 had penile hypospadias with bifid scrotum. Thus, patients carrying the same mutation may present with different phenotypes. A similar phenomenon was also described by Sinnecker et al: ${ }^{15}$ two brothers who carried homozygous R227Q mutations presented with different phenotypes: one had scrotal hypospadias with bifid scrotum and micropeins, and the other had only micropeins.

We identified two kinds of compound heterozygous mutations in SRD5A2 in four patients who all had scrotal hypospadias with bifid scrotum and micropenis. Patient 16, with Q6X and G203S, also had cryptorchism. His father, the carrier of Q6X, and his mother, the carrier of G203S, were all healthy. Patients 87,88 and 89 were brothers. They carried the same mutations (G203S and L224H) and presented with similar phenotypes. Their father was healthy and was the carrier of L224H. Canto et $\mathrm{al}^{16}$ reported a patient with penoscrotal hypospadias, who carried G203S and G115D, and studies indicated that the activity of SRD5A2 and the synthesis of DHT decreased in cultured genital skin fibroblasts carrying these mutations.

In this study, some heterozygous mutations in SRD5A2 were also found in five patients, healthy parents (Table 3) and controls. The role of heterozygous variants in disease occurrence is uncertain. $\mathrm{H} 232 \mathrm{H}$, which is novel and was found in one control out of 276 , is considered a rare SNP. It has been reported that over half of the affected individuals with steroid $5 \alpha$-reductase 2 deficiency were homozygotes, whereas $40 \%$ were either compound heterozygotes or inferred compound heterozygotes, suggesting that the carrier frequency of SRD5A2 mutations in the populations studied may be quite high. ${ }^{13}$ For these five patients, there might also be mutations that mapped outside of the exons and promoter region of $S R D 5 A 2$, which were not explored in our study.

For the V89L SNP in SRD5A2 (Table 4), 18\% of cases and $36 \%$ of controls had the wild-type G/G genotype $(P=0.007, \mathrm{OR}=2.56$ and $95 \% \mathrm{CI}=1.21-5.46)$. The frequency of the variant $\mathrm{C}$ allele is significantly elevated in cases compared to controls $(P=0.007, \mathrm{OR}=1.78$ and $95 \%$ $\mathrm{CI}=1.14-2.78$ ). This substitution results in approximately a $30 \%$ reduction in enzyme activity. ${ }^{17}$ These results suggest that the presence of the $\mathrm{C}$ allele is a genetic risk factor for hypospadias occurrence.

Homozygous and compound heterozygous mutations were found in nine out of 90 cases (10\%) in the present study, suggesting that SRD5A2 is a strong candidate gene for hypospadias. Our results indicated that genetic variants of SRD5A2 contributed to hypospadias, although there were no apparent correlations between the genotype and severity of phenotype.

Five mutations in the $A R$ gene were identified in six patients (46, XY), who are the hemizygotes for the $A R$ gene. $\mathrm{R} 840 \mathrm{H}$ was found in patient 86 with perineal hypospadias, bifid scrotum and micropenis. De Bellis A et al ${ }^{18}$ reported a subject with the same mutation, who had an ambiguous external genital phenotype. Androgen-binding affinity in genital skin fibroblasts of this subject was seven-fold lower than control, and the mutant receptor had reduced transcriptional activity. $\mathrm{R} 855 \mathrm{H}$ was found in patient 8 and his maternal uncle, patient 9 . These cases had perineal hypospadias, bifid scrotum and micropenis. $\mathrm{R} 855 \mathrm{H}$ has also been reported in two brothers with severe perineal hypospadias, bilateral cryptorchidism and micropenis. This amino-acid change is consistent with the more severe binding defect and clinical phenotype. ${ }^{19}$ R840H and $\mathrm{R} 855 \mathrm{H}$ are located in 'hot spot' regions, important for the formation and function of hormone-receptor complex 
and within regions that are involved in $\mathrm{AR}$ dimerization, and could lead to the functional defect of receptors. ${ }^{20,21}$ L859L, a synonymous mutation, was found in patient 1 with penile hypospadias, and it is unlikely to have a major impact on the patient phenotype.

All of the healthy fathers of patients 86,84 and 8 had normal genotypes, while all their healthy mothers were heterozygous for the mutations found in their sons. The healthy maternal grandmother of patient 84 was also heterozygous for the mutation found in her grandson. Patient 8 and his maternal-uncle, patient 9, had the same mutation. These findings indicate that mutations in $A R$ are transmitted according to the pattern of X-linked recessive disorders and play an important role in disease occurrence.

As the blood samples of normal children were difficult to collect, the mean age of controls was a little older than that of our patients. This is not likely to influence the findings from the present study as we focused on genomic variants that do not change with age, and we can be confident that the genitals of controls are normal as they were fully developed in adults.

A total of 24 patients out of the 90 studied (27\%) had some mutations in the SRD5A2, AR and WT1. Of these 24, 14 had micropenis (accounting for 58\%), whereas patients with micropenis accounted for $33 \%$ of all patients. This condition in patients 9,86 and 87 was so serious that they had to undergo penile reconstruction. Our findings of an association between mutations in $A R, S R D 5 A 2$ or $W T 1$ and micropenis are in contrast to prior reports showing no associations between mutations in $A R$ and SRD5A2 and micropenis. $^{22}$ This could be due to different racial compositions in patients in each study.

Mutations in the candidate genes studied were found in $27 \%$ of patients, indicating that mutations in SRD5A2, AR and $W T 1$ are associated with hypospadias. Only five patients had hypospadias without any associated anomalies, which is consistent with previous reports. ${ }^{23}$ Our results indicate that mutations are frequently found in genes that control androgen action and metabolism (SRD5A2, $A R$, $W T 1)$, but are seldom found in genes active in the early phase of sex determination and differentiation (SRY, SOX9).

Mutations in candidate genes were not found in $73 \%$ of our patients. Further studies should include evaluation of noncoding regions and the promoter areas of the candidate genes, other genes that mediate the process of male sex differentiation, abnormal expression of the genes, more detailed correlation between genotype and phenotype, and effects of certain environmental toxins.

\section{Acknowledgements}

We thank all the patients for their participation in this study, Professor Wilson HY Lo and Professor Jeanne M Manson for their helpful suggestion and revision of the manuscript, and Dr Dongyan Xia for statistical assistance. This work was supported by the National Natural Science Foundation of China (Grant39625007 \& 39993420), the China National Key Program on Basic Research (G1998051003) and Clinical Key Program of the Ministry of Health, China (Grant 20010409).

\section{References}

1 Paulozzi LJ: International trends in rates of hypospadias and cryptorchidism. Environ Health Perspect 1999; 107: 297-302.

2 Nordenskjöld A, Friedman E, Tapper-Persson M et al: Screening for mutations in candidate genes for hypospadias. Urol Res 1999; 27: $49-55$.

3 Stoll C, Alembik Y, Roth MP, Dott B: Genetic and environmental factors in hypospadias. J Med Genet 1990; 27: 559-563.

4 McElreavey K, Fellous M: Sex determination and the $\mathrm{Y}$ chromosome. Am J Med Genet 1999; 89: 176-185.

5 De Santa Barbara P, Bonneaud N, Boizet B et al: Direct interaction of SRY-related protein SOX9 and steroidogenic factor 1 regulates transcription of the human anti-Mullerian hormone gene. Mol Cell Biol 1998; 18: 6653-6665.

6 Shimamura R, Fraizer GC, Trapman J, Lau YFC, Saunders GF: The Wilms' tumor gene WT1 can regulate genes involved in sex determination and differentiation: SRY, Mullerian-inhibiting substance, and the androgen receptor. Clin Cancer Res 1997; 3: $2571-2580$.

7 Pelletier J, Bruening W, Li FP, Haber DA, Glaser T, Housman DE: WT1 mutations contribute to abnormal genital system development and hereditary Wilms' tumour. Nature 1991; 353: $431-434$.

8 Wilson JD, Griffin JE, Russell DW: Steroid 5 alpha-reductase 2 deficiency. Endocr Rev 1993; 14: 577-593.

9 Sasagawa I, Suzuki Y, Muroya K, Ogata T: Androgen receptor gene and male genital anomaly. Arch Androl 2002; 48: $461-466$.

10 Holterhus PM, Sinnecker GH, Hiort O: Phenotypic diversity and testosterone-induced normalization of mutant L712F androgen receptor function in a kindred with androgen insensitivity. J Clin Endocrinol Metab 2000; 85: 3245-3250.

11 Suzuki K, Fukabori Y, Nakazato H et al: Novel amino acid substitutional mutation, tyrosine-739-aspartic acid, in the androgen receptor gene in complete androgen insensitivity syndrome. Int J Androl 2001; 24: 183-188.

12 Sultan C, Lumbroso S, Paris F et al: Disorders of androgen action. Semin Reprod Med 2002; 20: 217-228.

13 Thigpen AE, Davis DL, Milatovich A et al: Molecular genetics of steroid 5 alpha-reductase 2 deficiency. J Clin Invest 1992; 90: 799-809.

14 Zhou L, Mei H, Liu T, Guang W: Identification of mutation of SRD5A2 gene and SRY gene in patients with hypospadias. Zhonghua Yi Xue Yi Chuan Xue Za Zhi 1999; 16: 311-314.

15 Sinnecker GH, Hiort O, Dibbelt L et al: Phenotypic classification of male pseudohermaphroditism due to steroid 5 alpha-reductase 2 deficiency. Am J Med Genet 1996; 63: 223-230.

16 Canto P, Vilchis F, Chavez B et al: Mutations of the 5 alphareductase type 2 gene in eight Mexican patients from six different pedigrees with 5 alpha-reductase-2 deficiency. Clin Endocrinol (Oxf) 1997; 46: 155-160.

17 Makridakis N, Ross RK, Pike MC et al: A prevalent missense substitution that modulates activity of prostatic steroid 5alphareductase. Cancer Res 1997; 57: 1020-1022.

18 De Bellis A, Quigley CA, Marschke KB et al: Characterization of mutant androgen receptors causing partial androgen insensitivity syndrome. J Clin Endocrinol Metab 1994; 78: 513-522.

19 Batch JA, Evans BA, Hughes IA, Patterson MN: Mutations of the androgen receptor gene identified in perineal hypospadias. J Med Genet 1993; 30: 198-201.

20 Imasaki $\mathrm{K}$, Hasegawa $\mathrm{T}$, Okabe $\mathrm{T}$ et al: Single amino acid substitution (840 Arg $\rightarrow$ His) in the hormone-binding domain of 
22 Sultan C, Paris F, Terouanne B et al: Disorders linked to

the androgen receptor leads to incomplete androgen insensitivity syndrome associated with a thermolabile androgen receptor. Eur J Endocrinol 1994; 130: 569-574.

21 Quigley CA, De Bellis A, Marschke KB, el-Awady MK, Wilson EM, French FS: Androgen receptor defects: historical, clinical, and molecular perspectives. Endocr Rev 1995; 16: 271-321. insufficient androgen action in male children. Hum Reprod Update 2001; 7: 314-322.

23 Baskin LS, Himes K, Colborn T: Hypospadias and endocrine disruption: is there a connection? Environ Health Perspect 2001; 109: $1175-1183$. 